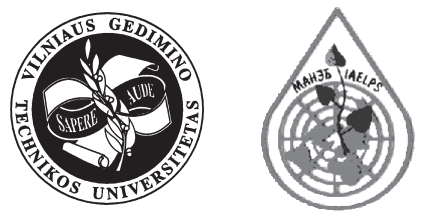

ISSN 1648-6897

JOURNAL OF ENVIRONMENTAL ENGINEERING AND LANDSCAPE MANAGEMENT

http:/www.vtu.lt/english/editions

2005, Vol XIII, No 1, 37-42

\title{
CHANGES OF IONIZING RADIATION CAUSED BY NATURAL RADIONUCLIDES IN THE CURONIAN SPIT
}

\author{
Milda Pečiulienė, Dainius Jasaitis, Gražina Grigaliūnaitẻ-Vonsevičienė, Aloyzas Girgždys
}

\author{
Laboratory of Nuclear Hydrophysics, Vilnius Gediminas Technical University, \\ Sauletekio al.11, LT-10223Vilnius-40,Lithuania.E-mail: algi@fm.vtu.lt
}

Received 30 Nov 2004; accepted 14 Dec 2004

\begin{abstract}
Taking into consideration a unique scenery of the Curonian Spit, dosimetric investigation of ionizing radiation caused by natural radionuclides is performed there. The influence of natural radionuclides present in the ground on the equivalent dose rate of gamma radiation in the ground surface air is established. Measurements of equivalent dose rate are carried out in the whole territory of the Curonian Spit in Lithuania. Especially numerous data have been collected on the coasts of the sea and bay, near them, in seaside dunes and by roads. The established equivalent dose rate values vary from $22 \mathrm{nSv} / \mathrm{h}$ (on the dune top) to $90 \mathrm{nSv} / \mathrm{h}$ (above an asphalt path). The values of the main gamma radiation source $\left({ }^{40} \mathrm{~K}\right.$ and $\left.{ }^{226} \mathrm{Ra}\right)$ concentration are measured, and positive correlation of concentrations and equivalent dose rates in the ground surface air between ${ }^{40} \mathrm{~K}$ and ${ }^{226} \mathrm{Ra}$ is determinated. It is established that ${ }^{40} \mathrm{~K}$ has the biggest influence on equivalent dose rate. The equivalent dose rate values in the ground surface air in the Curonian Spit are comparatively low (they can even be 1630 times lower in comparison to Guarapari beach, Brazil).
\end{abstract}

Keywords: ionizing radiation, natural radionuclides, dosimetry, equivalent dose rate in the ground surface air, concentration.

\section{Introduction}

The Curonian Spit is a long and narrow sand peninsula between the Baltic Sea and the Curonian Bay (abr Neringa). Its $52 \mathrm{~km}$ of it belong to Lithuania. A national park has been established there since 1991. There are 2 national reservoirs, 4 natural reserves, 4 ethnocultural and 2 urban reserves.

The history of the Baltic Sea began 13000 years ago when shifting glacier formed the Baltic ice lake. The current size and bowl of the Baltic Sea approximately were formed in Litorin Sea Period, that is 7500-7000 years ago. The same period saw the development of characteristic features of the Lithuanian scenery and emergence of the Curonian Spit and Bay [1].

Nowadays Neringa is one of the most popular Lithuanian resorts. Therefore, it is important to evaluate ionizing radiation influence on people who live or are on holiday there.

Studies on radiation levels and radionuclide distribution in the environment are important for several reasons. Baseline information on radiation levels and radionuclide distribution in the environment is essential for understanding human exposure to natural sources of radiation and distinguishing from it man-made contributions. Since natural radiation is the main source of human exposure, studies of the dose from this source and its effects on human health improve the understanding of radiation damage [2]. Equivalent dose rate is the main parameter reflecting the influence of ionizing radiation on a person. Accumulation of data on radiation levels of a region is also essential in establishing rules and regulations on protection from radiation [3].

This paper aims at defining doses the target of which are the holidaymakers on the Curonian Bay coasts.

\section{Investigation methods}

The Curonian Spit region in the Lithuanian territory was investigated in order to find possible pollution sources.

Mobile equipment for measurements, data registration and accumulation was used in the investigation. Measurements were carried out on the seaside, bay side, seaside and bay side dunes, by roads and in forests.

Fig 1 shows the measurement trajectories in the Curonian Spit. Distances between the points along the therritory are $500 \mathrm{~m}$, and across it $-200 \mathrm{~m}$ (the points 


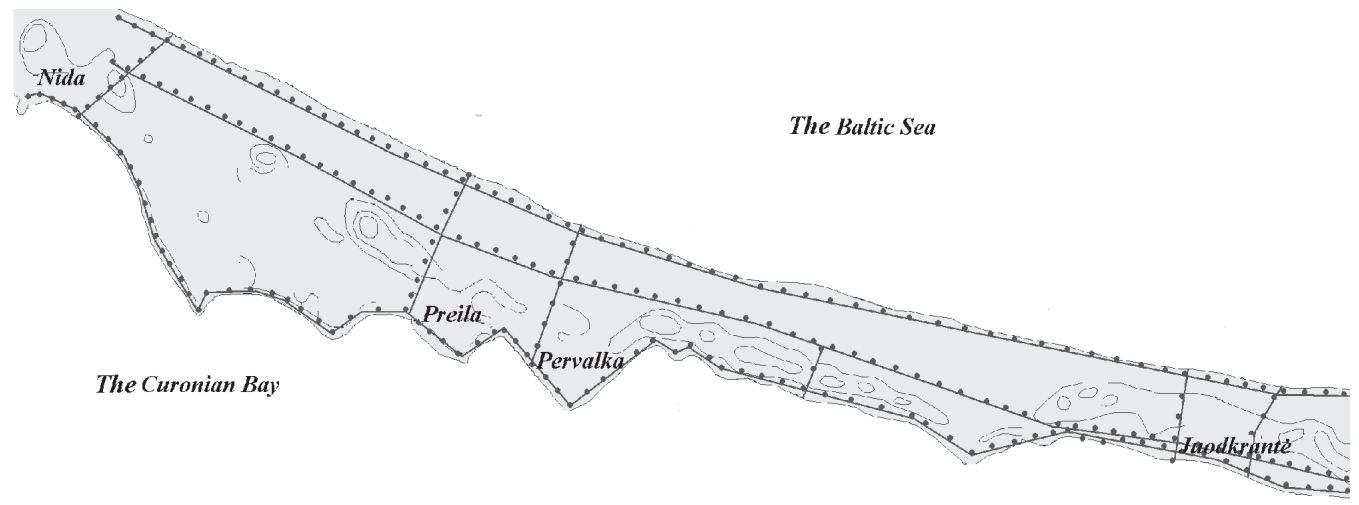

Fig 1. Measuring trajectories in the Curonian Spit

show the places of measurements).

The equipment depicted in Fig 2 was used to carry out the measurement of gamma radiation equivalent dose rate caused by natural radionuclides present in the ground.

Equivalent dose rate was measured with a portable radiometer SRP-08-01. During measurement the equipment detector was kept $1 \mathrm{~m}$ above a measured surface. The exposure dose measurement limits of the radiometer SRP-08-01 are 0-27000 $\mathrm{nSv} / \mathrm{h}$. Equivalent dose rate above different surfaces can be measured with this equipment.

The radiometer is connected to a data register from which accumulated data are transferred to a portable computer. The portable computer is connected to the Global Positioning System (GPS). The latter is a very precise radio navigation system providing information about the position of objects in space, their velocity, direction and covered distance, the distance to selected points, exact time at a given moment and geographical sunrise/sunset time and moon phases of a given location. GPS works in the same way in any place of the world irrespective of weather conditions, day time or season [4].

The following data are accumulated in the portable computer: location co-ordinates, time and readings of the radiometer. Radiometrical measurements were carried out continuously along the measurement route. While notic-

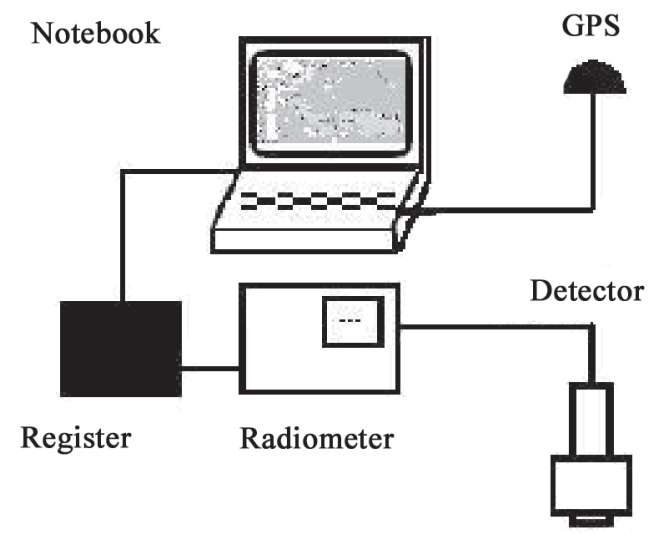

Fig 2. Measuring equipment ing increased equivalent dose rate, the same territory was measured additionally and slower.

The equipment is easily transported, therefore, it is easy to evaluate changes of equivalent dose rate in a big measurement territory.

With the aim of measuring more precisely the influence of the main gamma radioactivity sources ${ }^{40} \mathrm{~K}$ and ${ }^{226} \mathrm{Ra}$ on irradiance, their concentration in the ground of equivalent dose rate measurement places was evaluated. To identify the consentration, the gamma spectrometry was used. The ground was taken with a special recipient. A metal ring of $15 \mathrm{~cm}$ diameter and $5 \mathrm{~cm}$ height was hammered into the ground, the ground was separated with a spade while taking a sample. The samples were transported to the laboratory in plastic bags. In the laboratory the samples were weighted and put into a vessel of $200 \mathrm{ml}$ volume.

A gamma spectrometric system (CAMBERRA) was used to establish the concentrations of natural radionuclides. To identify the concentration of natural radionuclides in the ground, a sample sensor distinguishes them by a high differential power $(2 \mathrm{keV})$. The signal of the equipment is linear with a wide energy interval. The impulse amplitude is insensible to impulse counting velocity, high impulse-increasing speed and to magnetic fields.

The concentration in the ground of main gamma radiation sources is identified by using 24-72 hour measurement expositions. Radionuclides were identified according to the following lines: ${ }^{226} \mathrm{Ra}-186 \mathrm{keV}$, o ${ }^{40} \mathrm{~K}-$ $1460 \mathrm{keV}$.

The phon was evaluated continuously during the measurement period. The phon level varied little. Its ${ }^{40} \mathrm{~K}$ changes made up less than $4 \%$ of signal volume.

\section{Measurement results}

According to the above described dosimetry measurement methods, investigation of dosimetry in the ground surface air was performed in the Curonian Spit.

Information about equivalent dose rate distribution in space was collected due to a continuous data registration. That was very important for radiometrical investi- 
gation in the Curonian Spit. Ionizing and cosmic radiation of radioactive substances, found in the air and on the surface of the earth, causes equivalent dose rate in the earth surface air [5].

Fig 3 depicts the results of equivalent dose rate measurements in the surface ground in the Curonian Spit.

It is obvious from the figure that equivalent dose rate values differ. They mostly depend upon the bed surface type, because firstly gamma radiation depends upon the quantity of radionuclides in the ground (different composition of the ground). Another reason is shortlife-time radon split products present in the air and their different distribution in the surface ground. The figure shows that the lowest dose rate in the surface ground was found on the seaside beach (from $22 \mathrm{nSv} / \mathrm{h}$ to $60 \mathrm{nSv} / \mathrm{h}$ ), the highest one - above asphalt concrete surfaces (from $57 \mathrm{nSv} / \mathrm{h}$ to $90 \mathrm{nSv} / \mathrm{h}$ ). This natural radioactive radiation change could be explained by the influence of anthropogenic activity, therefore, the figure clearly shows urban territories and roads.

Table 1 indicates minimum, maximum and approximate values of equivalent dose rate in the ground surface air. While comparing approximate values, it can be noticed that the equivalent dose rate values above gravel and forest ground are the biggest. The values of equivalent dose rate of the latter are by about $40 \%$ higher than those of the rest. The variation interval of the equivalent dose rate in the ground surface air in seaside dunes in comparison to the others mentioned in Table 1 is the widest. The equivalent dose rate received by a person on the beach in three hours reaches about $130 \mathrm{nSv}$.

Fig 4 depicts the distribution values of equivalent dose rate in Juodkrante territory. The highest equivalent dose rate values were identified in towns near roads (above asphalt and concrete surfaces). Lower values were found during measurements above the forest ground and seaside sand and dunes. Higher values were found in Juodkrante, the Curonian Bay side because major part of the side is covered with stones and special concrete side fortifications.

The concentration in the ground and equivalent dose rate in the ground surface air above the sample collection place of the main gamma radiation sources ${ }^{40} \mathrm{~K}$ and ${ }^{226} \mathrm{Ra}$ were measured. Correlation between equivalent dose rate ${ }^{40} \mathrm{~K}$ and ${ }^{226} \mathrm{Ra}$ concentration in the ground was
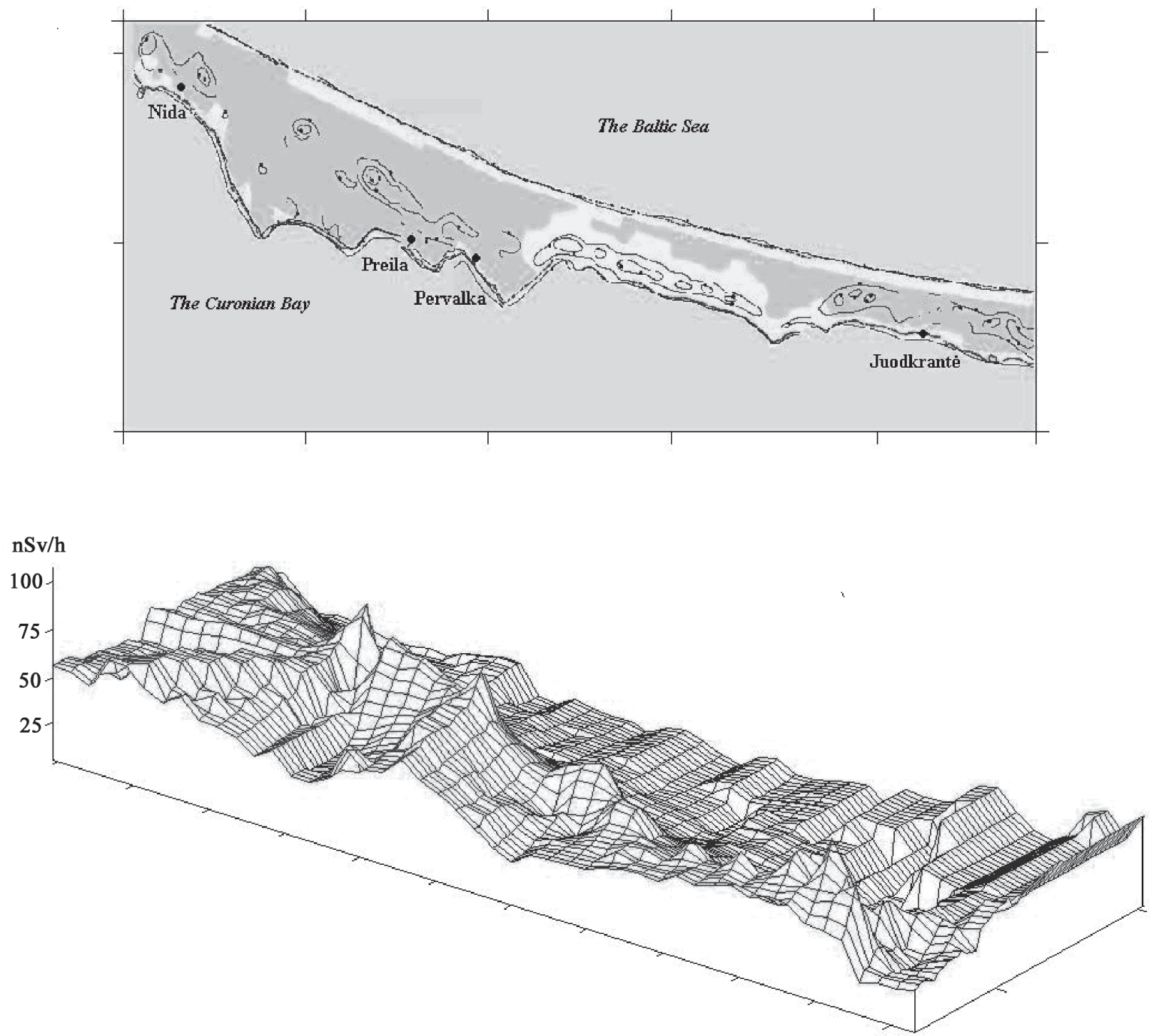

Fig 3. Distribution values of equivalent dose rate in the Curonian Spit 
Table 1. Measured equivalent dose rate in the ground surface air above different bed surfaces

\begin{tabular}{|l|c|c|c|c|}
\hline \multicolumn{1}{|c|}{ Bed surface } & Minimal value (nSv/h) & Maximal values (nSv/h) & $\begin{array}{c}\text { Approximate values } \\
(\mathrm{nSv} / \mathrm{h})\end{array}$ & $\begin{array}{c}\text { Approximate squire } \\
\text { declination }(\mathrm{nSv} / \mathrm{h})\end{array}$ \\
\hline Seaside sand (against dune) & 22 & 60 & 35 & 1 \\
\hline Seaside sand (dune) & 24 & 87 & 44 & 3 \\
\hline Loam & 24 & 58 & 43 & 2 \\
\hline Forest ground & 48 & 89 & 64 & 1 \\
\hline Bayside sand (dune) & 36 & 46 & 40 & 2 \\
\hline Gravel & 55 & 89 & 68 & 2 \\
\hline
\end{tabular}

established (Table 2). The identified correlation between ${ }^{40} \mathrm{~K}$ and ${ }^{226} \mathrm{Ra}$ concentration in the ground is positive. According to the data [5], correlation coefficient of the same radionuclides present in water reservoir (lake) ground equals to 0,82 .

It was observed that among the investigated radionuclides, ${ }^{40} \mathrm{~K}$ concentration was the biggest. Equivalent dose rate in the surface ground air is determined by ${ }^{40} \mathrm{~K}$, short-life-time ${ }^{226} \mathrm{Rn}$ split products and cosmic radiation.

According to the data [6], external equivalent dose rate caused by ${ }^{40} \mathrm{~K}$ radiation approximately makes up $33 \%$ of the value of equivalent dose rate in the ground surface air. According to the investigation results, ${ }^{40} \mathrm{~K}$ concentration is 20 times greater than that of ${ }^{226} \mathrm{Ra}$. Besides, gamma radiation energy is greater $\left({ }^{226} \mathrm{Ra}-\right.$ $\left.186 \mathrm{keV},{ }^{40} \mathrm{~K}-1460 \mathrm{keV}\right)$. It is known that major part of ${ }^{226} \mathrm{Ra}$ split products $\left({ }^{214} \mathrm{~Pb},{ }^{214} \mathrm{Bi},{ }^{210} \mathrm{~Pb}\right)$ that remain in the ground also have an approximately great influence upon equivalent dose rate.

The values of equivalent dose rate determined on the Curonian Spit beaches are compared to the results provided in literature [7] (Fig 5).

An approximate equivalent dose rate established in the Curonian Spit is $56 \mathrm{nSv} / \mathrm{h}$. The condition of the beach depends upon the geological composition of under-water side slope, outwash quantity and lito-dynamic situation. Above-water seaside is composed of sand beach and side dunes. Fine-grain sand dominates on the seaside. According to the radiometrical measurements performed, equivalent dose rate on the seaside is the lowest. Equivalent dose rate in the ground surface air is determined by ${ }^{40} \mathrm{~K}$ and ${ }^{226} \mathrm{Ra}$ radiation, therefore, their concentration was measured. The established values were equal, respectively, to $120 \mathrm{~Bq} / \mathrm{kg}$ and $13 \mathrm{~Bq} / \mathrm{kg}$. The

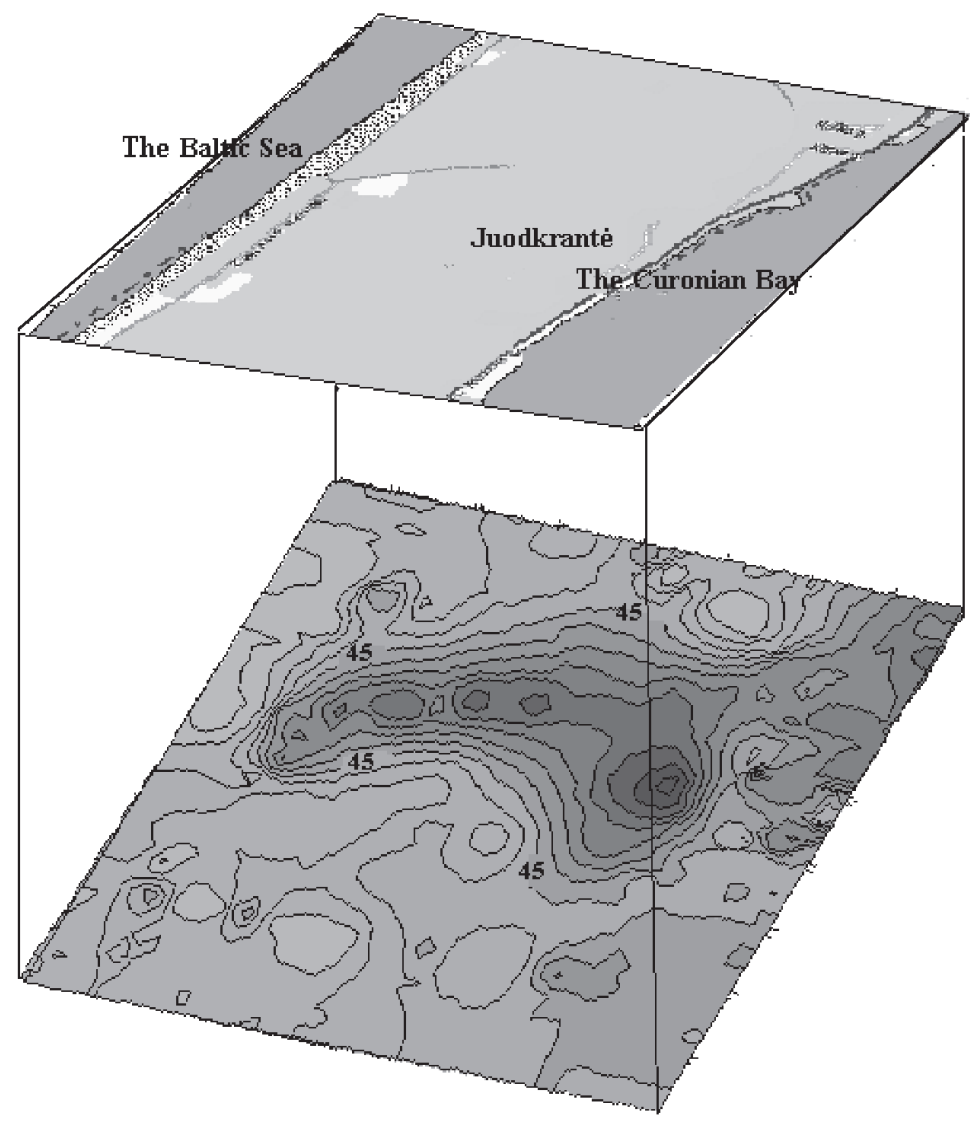

$\mathrm{nSv} / \mathrm{h}$

Fig 4. Distribution of equivalent dose rate values in Juodkrante 
Table 2. Correlation between equivalent dose rate in ground surface air and concentrations of radionuclides in the ground

\begin{tabular}{|l|c|c|c|}
\hline & $\begin{array}{c}\text { Equivalent } \\
\text { dose rate, } \\
\mathrm{nSv} / \mathrm{h}\end{array}$ & ${ }^{40} \mathrm{~K}, \mathrm{~Bq} / \mathrm{kg}$ & ${ }^{226} \mathrm{Ra}, \mathrm{Bq} / \mathrm{kg}$ \\
\hline $\begin{array}{l}\text { Equivalent dose } \\
\text { rate, } \mathrm{nSv} / \mathrm{h}\end{array}$ & 1 & & \\
\hline${ }^{40} \mathrm{~K}, \mathrm{~Bq} / \mathrm{kg}$ & 0,66 & 1 & \\
\hline${ }^{226} \mathrm{Ra}, \mathrm{Bq} / \mathrm{kg}$ & 0,69 & 0,81 & 1 \\
\hline
\end{tabular}

quantity of these radionuclides in sand is smaller than in clay and gravel bed surfaces.

Equivalent dose rate in the ground surface air on Guarapari beach surrounded by mountains (Brazil) is $91324 \mathrm{nSv} / \mathrm{h}$. Natural sloshing and washing of the waves tend to remove all of silt and clay from the soil. This concentrates the remaining heavy particles in sandy residue. Since most naturally occurring radioactive substances have large atomic mass numbers, they form very dense (and, therefore, heavy) compounds [7].

Equivalent dose rate in the ground surface air in Ramsar (Iran) is $79908 \mathrm{nSv} / \mathrm{h}$. These springs are named so because they are thermally hot, but as irony would have it, they are also radioactively "hot". All natural radioactive sources of radiation arise from the decay of unstable atomic nuclei. One of the products of these radioactive decays is radon gas which is found dissolved in the waters of many hot springs [7]. Radon gas is slightly denser than air and, therefore, tends to accumulate in depressions and basements. This gas is a strong emitter of alpha particles.

Equivalent dose rate in the ground surface air on Kerala beach (India) is $4006 \mathrm{nSv} / \mathrm{h}$. In this case the combination of naturally occurring radioactive minerals in the surrounding rock and the concentration of these minerals by geological processes has created soils which are enriched with radioactive elements [7].

Permanently evacuated equivalent dose rate in the ground surface air in Pripyat near Chernobyl (the Ukraine) reaches $572 \mathrm{nSv} / \mathrm{h}$. This is not a result of naturally occurring radiation from the surrounding soil, but it is inserted here for comparison purposes. In 1986 a nuclear reactor in Chernobyl began an uncontrolled, runaway nuclear reaction. The heat produced a massive steam explosion which released large amounts of radioactive substances into the environment. Luckily much of the high-level radiation was produced by radio isotopes with short half-lives, and the radiation levels quickly dropped. Nevertheless, the residual background radiation stabilized at a level which has been considered too high for human occupation [7].

Comparing these extreme dose values to the values established on Lithuanian beaches and the Curonian Spit, it is obvious that here the situation is far better. A holiday- maker during one hour on Guarapari beach receives a dose which equals to that received by a holiday-maker in the Curonian Spit during two months. The dose received in Pripyat during two months equals to that received in the Curonian Spit during one and a half year.

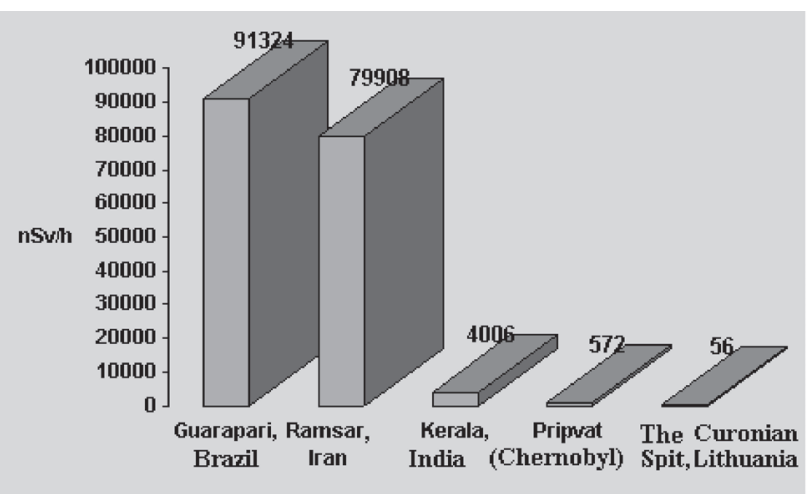

Fig 5. Equivalent dose rate values near Chernobyl, on beaches of Lithuania and in other countries

One-week vacation on Guarapari beach (Brazil) is equivalent to living for three years in the city of Pripyat near Chernobyl. Six months on Guarapari beach is equivalent to living for eighty years (almost a lifetime) in Pripyat.

\section{Conclusions}

1. Measured equivalent dose rate in the whole territory of the Curonian Spit (Lithuania) changes from $22 \mathrm{nSv} / \mathrm{h}$ (on dunes) to $90 \mathrm{nSv} / \mathrm{h}$ (above asphalt and concrete surfaces).

2. Gamma radiation equivalent dose rate depends upon a bed surface: for seaside sand $-35 \mathrm{nSv} / \mathrm{h}$, for seaside dunes $-44 \mathrm{nSv} / \mathrm{h}$, for loam $-43 \mathrm{nSv} / \mathrm{h}$, for forest ground $-64 \mathrm{nSv} / \mathrm{h}$, for bayside sand $-40 \mathrm{nSv} / \mathrm{h}$ and for gravel $-68 \mathrm{nSv} / \mathrm{h}$.

3. Correlation between the concentration of radionuclides present in the ground $\left({ }^{40} \mathrm{~K}\right.$ and $\left.{ }^{226} \mathrm{Ra}\right)$ and equivalent dose rate in the surface ground air above a sample collection place is positive, respectively, 0,66 and 0,69 .

4. Equivalent dose rate values caused by ionization radioactivity on the Curonian Spit beaches are low and do not cause a big danger to human health.

\section{References}

1. Žaromskis, R. Oceans, seas, estuarys (Okeanai, jūros, estuarijos). Vilnius: Debesija, 1996, p 178-182 (in Lithuanian).

2. Quindos, L. S.; Fernandez, P. L.; Soto, J.; Rodenas, C.; Comez, J. Natural radioactivity in Spanish soils. Health Physics, No 66(2), 1994, p 194-200.

3. Ziqiang, P.; Yin, Y.; Mingquiang, G. Natural radiation and radioactivity in China. Radiation Protection. Dosim., No 24 (114), 1988, p 29-38.

4. Global Positioning System: http://www.gpsworld.com/ gpsworld.

5. Jasaitis, D.; Pečiulienè, M.; Girgždys, A. Evaluation of radionuclide concentration in the bottom ground of water reservoirs and waterside ground. Journal of Environmental Engineering and Landscape Management, Vol XII, No 3, 2004, p 85-90. 
6. Konstantinova, M.; Butkus, D. Estimation of exterior equivalent dose rate caused by natural-origin gamma radiation present in the soil. Health Sciences, No 3. Vilnius,
2003, p 50-54 (in Lithuanian).

7. Terrestrial sources of radiation: http://resources.yesican. yorku.ca/trek/radiation/final/earth_sources.html.

\title{
GAMTINĖS KILMĖS RADIONUKLIDŲ SUKELTOS JONIZUOJANČIOSIOS SPINDULIUOTĖS KAITA KURŠIŲ NERIJOJE
}

\author{
M. Pečiulienè, D. Jasaitis, G. Grigaliūnaitè-Vonsevičienè, A. Girgždys
}

S a n tra u a

Atsižvelgiant ị Kuršių nerijos kraštovaizdžio unikalumą, joje buvo atlikti gamtinės kilmės radionuklidų sukeltos jonizuojančiosios spinduliuotès dozimetriniai tyrimai. Nustatyta dirvožemyje esančių gamtinès kilmès radionuklidų įtaka gama spinduliuotės lygiavertès dozès galiai pažemio ore. Lygiavertès dozès galios matavimai atlikti visame Kuršių nerijos regione Lietuvos teritorijoje, ypač daug duomenų surinkta jūros ir mariu pakrantėse, pajūrio ir pamario kopose ir prie kelių. Nustatytos lygiavertės dozės galios vertès kinta nuo $22 \mathrm{nSv} / \mathrm{h}$ (ant kopos) iki $90 \mathrm{nSv} / \mathrm{h}$ (virš asfaltuoto tako). Išmatuotos pagrindiniu gamtiniu gama spinduoliu ( ${ }^{40} \mathrm{~K}$ ir ${ }^{226} \mathrm{Ra}$ ) savitujų aktyvumų dirvožemyje vertės bei gautas teigiamas koreliacinis ryšys tarp ${ }^{40} \mathrm{~K},{ }^{226} \mathrm{Ra}$ savitujų aktyvumų ir lygiavertès dozès galios pažemio ore virš bandinio èmimo vietos. Pastebèta, kad didžiausios ittakos lygiavertès dozès galiai turi gamtinès kilmès radionuklidas ${ }^{40} \mathrm{~K}$. Lygiavertès dozès galios vertès Kuršių nerijos paplūdimių pažemio ore yra palyginti mažos (gali būti net 1630 kartų mažesnès, palyginti su Guarapari paplūdimiu Brazilijoje).

Raktažodžiai: jonizuojančioji spinduliuotè, gamtinès kilmès radionuklidai, dozimetrija, lygiavertès dozės galia pažemio ore, savitasis aktyvumas.

\section{ИЗМЕНЕНИЯ ИОНИЗИРУЮЩЕГО ИЗЛУЧЕНИЯ, ПРОИЗВОДИМОГО ЕСТЕСТВЕННЫМИ РАДИОНУКЛИДАМИ, НА КУРШСКОЙ КОСЕ}

\section{М. Пячулене, Д. Ясайтис, Г. Григалюнайте-Вонсявичене, А. Гиргждис}

Р е 3 ю м е

С учетом уникальности ландшафта Куршской косы были проведены дозиметрические испытания ионизирующего излучения, производимого естественными радионуклидами. Определена мощность эквивалентной дозы излучения, производимого естественными радионуклидами, находящимися в грунте. Измерения мощности эквивалентной дозы излучения проводились по всему региону Куршской косы на территории Литвы. Особенно тщательно были собраны данные на побережье Балтийского моря и Куршского водоема, в прибрежных дюнах и вдоль дорог. Полученные значения мощности эквивалентной дозы излучения колеблются от $22 \mathrm{nSv} / \mathrm{h}$ (в дюнах) до $90 \mathrm{nSv} / \mathrm{h}$ (над асфальтом). Определена удельная активность основных естественных гамма-излучателей $\left({ }^{40} \mathrm{~K}\right.$ и $\left.{ }^{226} \mathrm{Ra}\right)$ для грунта, а также положительная корреляционная связь между удельной активностью ${ }^{40} \mathrm{~K},{ }^{226} \mathrm{Ra}$ и мощностью эквивалентной дозы излучения в воздухе над местом взятия пробы. Определено, что наибольшее влияние на мощность эквивалентной дозы излучения оказывает радионуклид естественного происхождения ${ }^{40} \mathrm{~K}$. Значения мощности эквивалентной дозы излучения на пляжах Куршской косы сравнительно небольшие (возможно, в 1630 раз меньше, чем на пляже Гуарапари в Бразилии).

Ключевые слова: ионизирующее излучение, естественные радионуклиды, дозиметрия, мощность эквивалентной дозы излучения, удельная активность.

Milda PEČIULIENĖ. Master, doctoral student, Dept of Physics, Vilnius Gediminas Technical University (VGTU), Saulètekio al. 11, LT-10223, Vilnius, Lithuania. E-mail:milda@fm.vtu.lt

Doctoral student (physics), VGTU, 2002. Master of Ecology, VGTU, 2000. Publications: co-author of 4 research papers. Research interests: environmental physics, natural radioactivity, anthropogenic impact.

Dainius JASAITIS. Master, doctoral student, Dept of Physics, Vilnius Gediminas Technical University (VGTU), Sauletekio al. 11, LT-10223, Vilnius, Lithuania. E-mail: dainiusj@fm.vtu.lt

Doctoral student (environmental engineering), VGTU, 2003. Master of Ecology, VGTU, 2002. Publications: co-author of 3 research papers. Research interests: environmental physics, natural radioactivity, ionizing radiation.

Gražina GRIGALIŪNAITĖ-VONSEVIČIENĖ. Dr, Assoc Prof, Dept of Physics, Vilnius Gediminas Technical University (VGTU), Saulètekio al. 11, LT-10223, Vilnius-40, Lithuania.

Doctor of Physics, VGTU, 2001. Master of Physics, Vilnius Pedagogical University, 1997. Research interests: semiconductor physics, environmental physics.

Aloyzas GIRGŽDYS. Dr, deputy director (since 1986) of Institute of Physics, Savanoriu g. 231, LT-02300 Vilnius, Lithuania. E-mail: algi@fm.vtu.lt

Doctor of Science (environmental physics), Moscow Institute of Atmospheric Physics, 1985. First degree in Physics, Vilnius University (VU), 1970. Publications: author of 1 monograph, over 120 research papers. Research interests: environmental physics, aerosol physics. 